\title{
Are in situ weight-specific growth rates body-size independent in marine planktonic copepods? A re-analysis of the global syntheses and a new empirical model
}

\author{
Andrew G. Hirst*, Martin Sheader \\ Department of Oceanography, University of Southampton, Southampton Oceanography Centre, Empress Dock, \\ Southampton SO14 3ZH, United Kingdom
}

\begin{abstract}
The dependency of in situ weight-specific growth rates of marine copepods upon individual body size (weight) was examined by compiling literature values. Two predictive models were compared to the compiled values, one in which weight-specific growth rate of individuals is dependent upon body size and temperature, and another in which weight-specific growth rate is dependent upon temperature but independent of individual body size. By comparing predictions from the models with the compiled values, it is shown that the former model is a better predictor of weight-specific growth rates for marine copepods under most conditions. Temperature and body weight are of influence upon weight-specific growth rates for the whole data set (which includes adult, juvenile and mixed growth types), rates declining with increasing size. Allometric scaling coefficients of $b=0.581$ to 0.737 were found when adult weight-specific fecundity and juvenile weight-specific growth are considered together, while the significant relationships give $b$ values of 0.706 and 0.739 when juvenile growth was considered alone. These are similar to those describing other metabolic rates. No significant relationship was found for weight-specific fecundity and body weight, although the data set was very limited. Copepod generation times were shown to be weight dependent when compared to the combined geometric mean of egg and adult weights rather than adult weight alone. By combining data from the literature, a new globally applicable empirical equation was constructed which allows predictions of the weight-specific growth rates of copepods from body weight and temperature. Given that many mesoand macrozooplankton samples are dominated by copepods, it is suggested that this equation may be the most appropriate for estimation of growth and production for suites of such organisms when there is a lack of growth rate data available.
\end{abstract}

KEY WORDS: Copepods - Weight-spectic growth Weight-specific fecundity Allometry Temperature . Generation time

\section{INTRODUCTION}

Copepods are important grazers and nutrient recyclers in the marine environment, and are the dominant trophic link between primary production and fish. Measuring and gaining an understanding of zooplankton grazing, processing and production is essential in fully appreciating their role in energy and nutrient

\footnotetext{
- Present address: George Deacon Division, Southampton Oceanography Centre, Empress Dock, Southampton SO14 3ZH, UK.E-mail: a.hirst@soc.soton.ac.uk.
}

flow and transformation. Estimating in situ copepod growth rates is time consuming and effort intensive, even under conditions where cohorts are identifiable. Often natural growth rates cannot be determined without manipulation, incubation techniques have therefore commonly been used, though difficulties may arise if conditions are not representative of those in the field. Several biochemical methods that allow estimation of growth without incubation have been developed (e.g. enzyme activities, RNA concentrations), but some of these have problems and have been criticized (Dagg \& Littlepage 1972). 
Models typically utilize a few easily measurable parameters such as temperature, biomass and size distribution (e.g. Ikeda \& Motoda 1978. Huntley \& Boyd 1984. Huntley \& Lopez 1992), and allow fast and low effort estimation of growth and production without the need for incubation. However, these models have not always been rigorously tested, and may give estimates which are unrealistic. Two models which give estimates of natural rates of copepod growth are examined here.

The first of these, the Ikeda \& Motoda (1975) model, estimates growth from size-distributed biomass and temperature. It has been applied in several studies (Ikeda \& Motoda 1975, 1978, Joh \& Uno 1983, Koga 1986. Uye et al. 1987). The main criticism of this model is that many assumptions are made in achieving a final temperature- and weight-dependent growth rate, including the use of a single assimilation efficiency of 0.7 and a gross growth efficiency of 0.3 . Such efficiencies, howcver, may change with body size and temperature (e.g. Ross 1982). For example, assimilation efficiencies for herbivorous zooplankton may be particularly variable, ranging from $\sim 30$ to $>90 \%$ (Alldredge 1984 , Dmori \& Ikeda 1984). The second model, that of Hunt ley \& Lopez (1992), estimates growth from temperature alone. Predictions from this model have been compared to field copepod data in several studies (Hay 1995, McKinnon 1996). As the model is derived from adult and egg weight, and from generation times of marine copepods, it assumes that growth is exponential, the data is therefore insensitive to sub-generation variability of growth (Kleppel et al. 1996). The model is also only constructed from juvenile growth, and yet meant for both juvenile and adult predictions. Results from the Huntley-Lopez model appear to show that juvenile growth is always food saturated in nature; however, evidence suggests that growth of adults and juveniles can often be severely food limited under natural conditions (e.g. Burkill \& Kendall 1982, Kimmerer \& McKinnon 1987, Peterson et al. 1991)

These 2 models differ in their application in 1 major respect $_{i}$ in the Ikeda-Motoda model, growth rate is a function of temperature and body size, whereas in the Huntley-Lopez model temperature is the only dependent function. The Ikeda-Motoda model predicts that growth declines with body size, whereas the HuntleyLopez model predicts weight independence. Although intra-specific growth may decrease with increasing body weight, with larger individuals growing more slowly than smaller individuals (Zaika 1968, Zaika \& Malovitskaya 1968, Vidal 1980, Aksnes \& Magnesen 1988, Hutchings et al. 1995, Peterson \& Hutchings 1995 ), this is certainly not always the case, and there is no apparent single rule (Huntley \& Lopez 1992) In this investigation, among-species patterns are examined.
Individual body weight would certainly appear to affect almost all physiological processes in marine zooplankton and copepods, with the general rule that small organisms have higher respiration, excretion, and ingestion demands per unit biomass than larger ones. Body size is an integral component of the physiological method of Ikeda \& Motoda (1978) because of the apparent body-weight dependence of weight-specific respiration. The aim of this study is to determine whether the weight-specific growth rates of planktonic marine copepods are body size independent, and to determine which model is the better predictor of in situ copepod growth rates. A new empirical equation relating growth in copepods to temperature and body weight is also derived from the data set.

\section{METHODS}

The models. The 2 models examined are outlined below. The first, and the more simple to apply, is the Huntley-Lopez growth model, which is described by the cquation:

$$
g=0.0445 \mathrm{e}^{0.111 T}
$$

where $g$ is individual weight-specific growth rate $\left(\mathrm{d}^{-1}\right)$ and $T$ is the temperature $\left({ }^{\circ} \mathrm{C}\right)$.

The second method is that given by Ikeda \& Motoda $(1975,1978)$. This estimates growth from respiration, which is described by an empirically derived equation relating respiration to body weight and temperature. The relationship between respiration rate $\left(R, \mu \mathrm{O} \mathrm{O}_{2}\right.$ ind..$\left.^{-1} \mathrm{~h}^{-1}\right)$, habitat temperature $\left(T,{ }^{\circ} \mathrm{C}\right)$ and individual animal dry weight $(W, \mathrm{mg}$ ) as determined by Ikeda (1974) is:

$$
R=a W^{b}
$$

where $a=10^{0.02538 T-0.1259}$ and $b=-0.01089 T+0.8918$. Oxygen respired is then converted to carbon using a respiratory quotient of 0.8 , and to daily rates by multiplying by 24. Assuming an assimilation efficiency of 0.7 and a gross growth efficiency of 0.3 , daily weightspecific growth $\left(g, \mathrm{~d}^{-1}\right)$ is given as:

$$
g=\frac{7.714 \times 10^{002538 T-0.1259} \times W^{-0.01089 T+0.8918}}{W_{C}}
$$

where $W_{C}$ is individual animal weight in $\mu \mathrm{g} C$.

Since this paper aims to determine which of the models predicts best on a global scale, both models were applied to copepods without imposing limits to temperature or body weight. The Huntley-Lopez model was defined by the authors as globally applicable, being derived from copepod measurements made at the tropics to the poles, while the Ikeda-Motoda model was derived from respiration measurements of 
meso- and macrozooplankton from boreal to tropical regions

Weight-specific growth rates, comparing the models. Data for this analysis were taken from published studies of planktonic marine copepods where weightspecific growth rate $\left(\mathrm{d}^{-1}\right)$, temperature $\left({ }^{\circ} \mathrm{C}\right)$ and the body-weight estimates were all available for individual stages or very short segments of the life cycle, typically 1 instar stage or for a single day. Growth rates in these studies were estimated using a variety of methods, including changes in total biomass in incubation containers, and by using moulting rate measurements combined with weight estimates. In the case of growth rate data presented by Chisholm \& Roff (1990b) weights for stages were taken from the accompanying paper (Chisholm \& Roff 1990a). In 2 cases growth rates were derived indirectly from the construction of energy budgets where other physiological components were measured (i.e. Gerber \& Gerber 1979, Schnack et al. 1985). In all studies, examinations were undertaken using short-term incubations, with feeding conditions as close to natural within the limits that current methods allow (i.e. incubation in natural seawater and at natural temperature, but with the removal of predators, over periods which do not allow food concentrations to decline greatly). As such, the rates were not truly in situ, and are better regarded as simulated in situ. At present in situ incubation techniques do not fully reproduce natural conditions, given. handling stress, alteration of food composition, patch destruction, restricted ambits and reduced turbulence. When individual body weights were not quoted in units of carbon, conversion from dry weight was carried out assuming a factor of 0.4 (Omori \& Ikeda 1984, Parsons et al. 1984, Båmstedt 1986). It should be noted that carbon as a percentage of dry weight may increase from tropical to polar regions (Bamstedt 1986), and therefore with average temperatures. However, given that the percentages range is from 28 to $63 \%$ (Bamstedt 1986), and growth is examined with respect to many orders of magnitude changes in body weight and over small temperature ranges, then using a single factor will not alter the general conclusions made herein. When growth rates were given as finite weight-specific growth (G), as in Chisholm \& Roff (1990b), they were converted to instantaneous weight-specific growth rates $(g)$ using the formula:

$$
g=\ln (G+1)
$$

No attempt was made to separate the species into broadcast and sac spawners, even though such distinction may have important consequences (see Kiorboe \& Sabatini 1995). Neither were they separated into order (e.g. Cyclopoids, Calanoids, etc.), since the models constructed and compared here are intended for wide- spread application to pelagic marine copepad communities. Although in the new empirical model both juvenile weight-specific growth and adult weight-specific fecundity are combined, these 2 forms of growth were also examined separately, as this is an issue of some contention (Kiørboe \& Sabatini 1995).

Determining whether generation time is bodyweight dependent. Huntley \& Lopez (1992) suggested that generation time was body-weight independent. In their analyses, generation time was regressed against log adult body weight. Re-analysis was undertaken in this study to allow for the range of body weights experienced by a given species at a given temperature over its entire life-history (i.e. range being from egg to adult weight), rather than simply applying the adult weight. With this in mind, tests were repeated upon the data set of Huntley \& Lopez (1992). Log 10 geometric mean weights were calculated and regressed against generation time; the same temperature ranges were used as in the Huntley \& Lopez study, except in the case of the 10 to $11^{\circ} \mathrm{C}$ group which was extended to allow temperature rounding (as occurred in the original study for the other groups)

\section{RESULTS}

\section{Empirical growth data}

The entire data for in situ conditions includes growth data collected at temperatures ranging from 0 to $29.85^{\circ} \mathrm{C}$, for individuals ranging in size from 0.018 to $511 \mu \mathrm{g} \mathrm{C}$, and from polar to tropical regions. It includes 70 measurements of juvenile weight-specific growth, 6 measurements of adult female weight-specific fecundity, and 17 measures of combined juvenile and adult or unspecified growth type. Backwards step-wise regression analysis was completed upon the entire data set with the dependent variable $\log _{10}$ weight-specific growth and the independent variables temperature and $\log _{10}$ body weight, with $F$-to-enter being set at 4.0 and $F$ to-remove at 3.9. The results of this analysis show that both temperature and $\log _{10}$ body weight should be included in the prediction. The growth rates were therefore combined into a multiple linear regression equation relating $\log _{1:}(g)$ to temperature and $\log _{10}\left(W_{c}\right)$. A multiple linear regression fit gave the expression

$$
\log _{10}(g)=0.0246 T-0.2962 \log _{10}\left(W_{C}\right)-1.1355
$$

This relationship has an $r^{2}=0.640 . \log _{10}(g)$ was predicted from a linear combination of the independent variables temperature $(\mathrm{p}<0.001)$ and $\log _{10}\left(W_{C}\right)(\mathrm{p}<$ 0.001 ). It is proposed that this equation may be used to predict copepod community growth rates, where there is no distinction as to the form of the copepod 


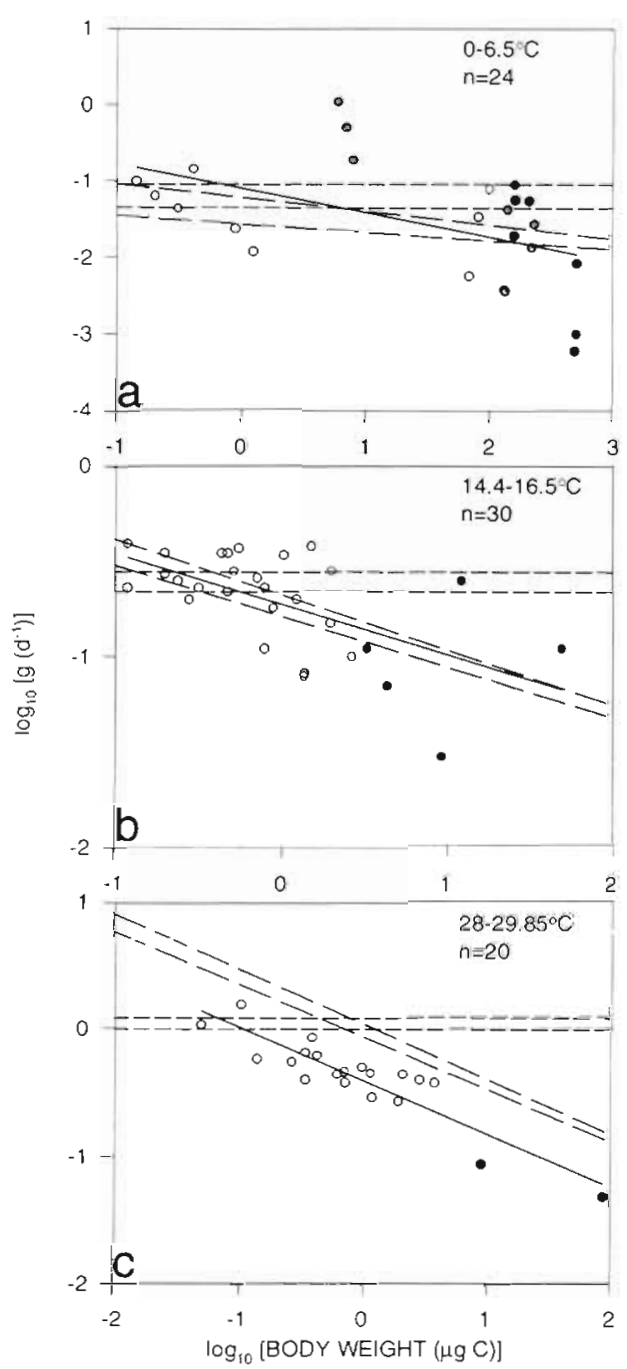

Fig. 1. Measured growth rates vs mean body weight at (a) 0 to $6.5^{\circ} \mathrm{C}$, (b) 14.4 to $16.5^{\circ} \mathrm{C}$, and (c) 28 to $29.85^{\circ} \mathrm{C}$. Data divided into small temperature ranges to reduce the effect which this factor has upon growth rates in each graph. Short dashed lines give predicted weight-specific growth rates at temperature extremes calculated using the Huntley-Lopez model. Long dashed lines give predicted weight-specific growth rates at temperature extremes calculated using the IkedaMotoda model. Type I least squares regression through data shown by unbroken line. (o) Juvenile growth; ( $\bullet$ adult female growth; (0) unspecified or adult and juvenile growth

biomass. The same analysis was repeated on the juvenile growth data alone, but not on the adult female growth (weight-specific fecundity) as this data was too limited with only 6 data points. For the juvenile data, growth was also predictable from the independent variables temperature $(p<0.001)$ and $\log _{10}$ body weight $(\mathrm{p}<0.001)$, with an $\mathrm{r}^{2}=0.738$. Backwards step-wise regression on this data once again showed that both variables should be included in the prediction.
The multiple linear regression clearly demonstrates decreasing weight-specific growth with increasing body weight for both juvenile growth, and for the entire data set. Relationships were examined further using a second method. Firstly, to reduce the effect of temperature, the entire data set of in situ growth rates was reorganised into relatively small temperature ranges. These ranges had a minimum interval of $1.85^{\circ} \mathrm{C}$, a maximum of $6.5^{\circ} \mathrm{C}$ (at the lowest temperature i.e. 0 to $6.5^{\circ} \mathrm{C}$ ) and a mean of $3.5^{\circ} \mathrm{C}$ (see Fig. 1). The Huntley-Lopez and Ikeda-Motoda predicted growth rates are also shown for the temperature extremes given in each group. For each of these groups a least squares regression (Type I) was completed, and tested for significance. Table 1 summarises the data used, including the range of temperatures for the compiled data, the range in body weight for the measurements, and number of species. There were significant negative relationships with $\log _{10}(g)$ declining with increasing $\log _{10}\left(W_{C}\right)$ for all 3 of the sets of data when juvenile, adult and mixed growth were included. When juvenile growth alone was considered, the 0 to $6.5^{\circ} \mathrm{C}$ group showed ru signilifican reldionship, but the 2 other temperature regimes still gave significant negative relationships. Adult growth was not significantly related to body weight for the temperature regime tested; however, there were only 5 data points (see Table 1). The regression residuals were all tested for normality using the Kolmogorov-Smirnov test ( $\mathrm{p}=$ 0.05), and in all cases passed. The results of this compilation study suggest therefore, that juvenile copepod weight-specific growth is body-weight dependent under short-term natural food incubations. When considering the entire data set, growth was also bodyweight dependent.

\section{Weight-specific growth rates, comparing the models}

The original weight-specific growth rate measurements compiled are given in Appendix 1. In comparing predicted rates with measured rates, paired t-tests could not be used as the data failed normality tests (where the probability level was set at $p=0.05$ ). The non-parametric Wilcoxon signed rank test was therefore used as an alternative.

Predicted growth rates from both the Huntley-Lopez model and the Ikeda-Motoda model were significantly different from the measured values $(p<0.001$ ). The empirically derived MLR model predicted results were not significantly different from the measured values $(\mathrm{p}=0.559)$, although, of course, the model lacks independence from the measured data. Graphical comparisons of predicted and measured growth rates are given in Fig 2. 
Fig. 2. Comparisons between measured growth rates and predicted growth rates generated using the Huntley-Lopez, Ikeda-Motoda and multiple linear regression models. Solid line shows a $1: 1$ relationship
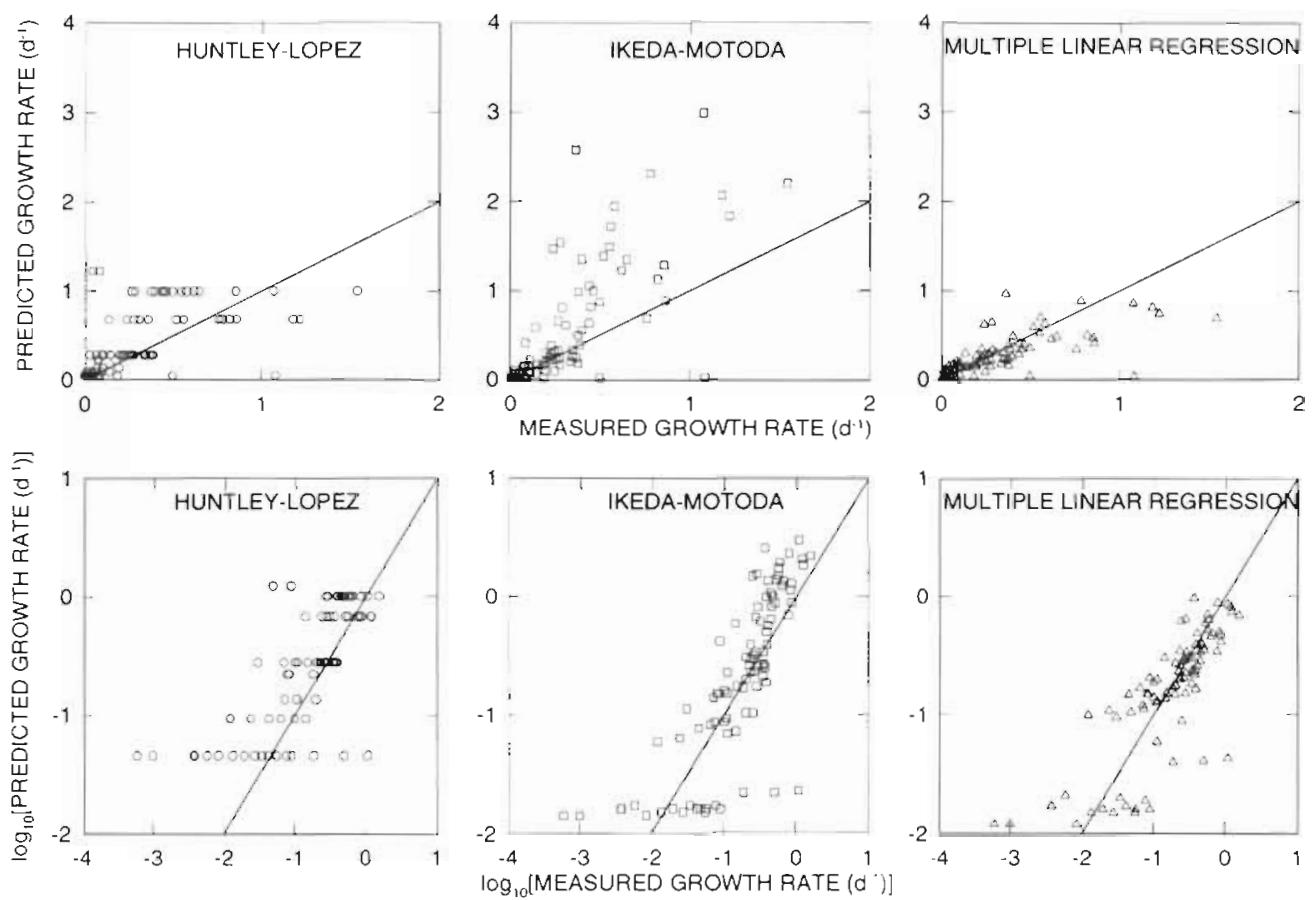

\section{Determining whether generation time is body-weight dependent}

A summary of the data sets in this analysis is given in Table 2, and shown graphically in Fig. 3. Generation time increased as $\log _{10}$ body weight increased, except for one case (the 19.5 to $21.4^{\circ} \mathrm{C}$ group), which had relatively few data points. Increase in generation time with increasing body weight is not evidence that growth is weight dependent, as egg weight as a proportion of adult weight is constant in sac spawners and decreases with increasing adult size in broadcast spawners (Kiørboe \& Sabatini 1995) However, if in situ generation time were in fact bodyweight independent as described by Huntley \& Lopez (1992) then this would be difficult to reconcile with declining in situ juvenile growth with increasing body weight, as found here.

\section{DISCUSSION}

In this study the compiled data of in situ growth rates showed significant negative relationships between weight-specific growth rate and individual body size for juvenile growth when divided into small temperature
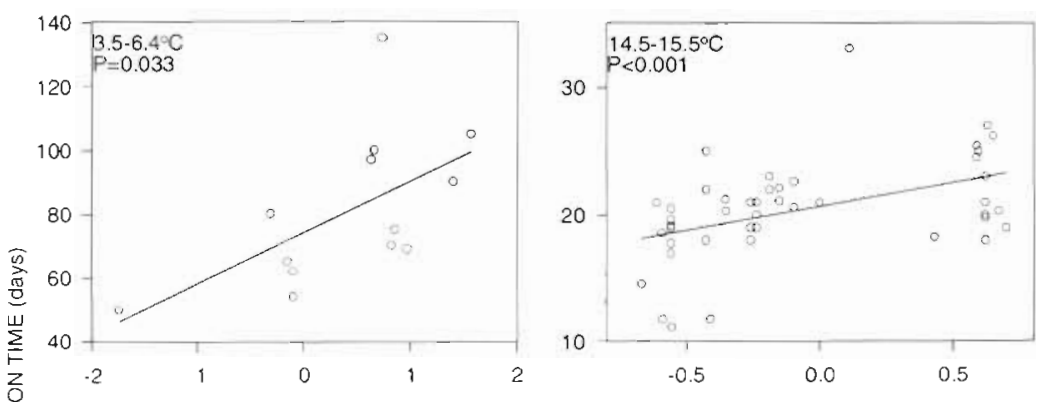

ranges. Juvenile and adult growth together gave significant negative relationships, although the data were dominated by juvenile rates. Multiple linear regression analysis also demonstrated that both temperature and body weight were significantly related to weight-specific growth for juveniles alone, and for 

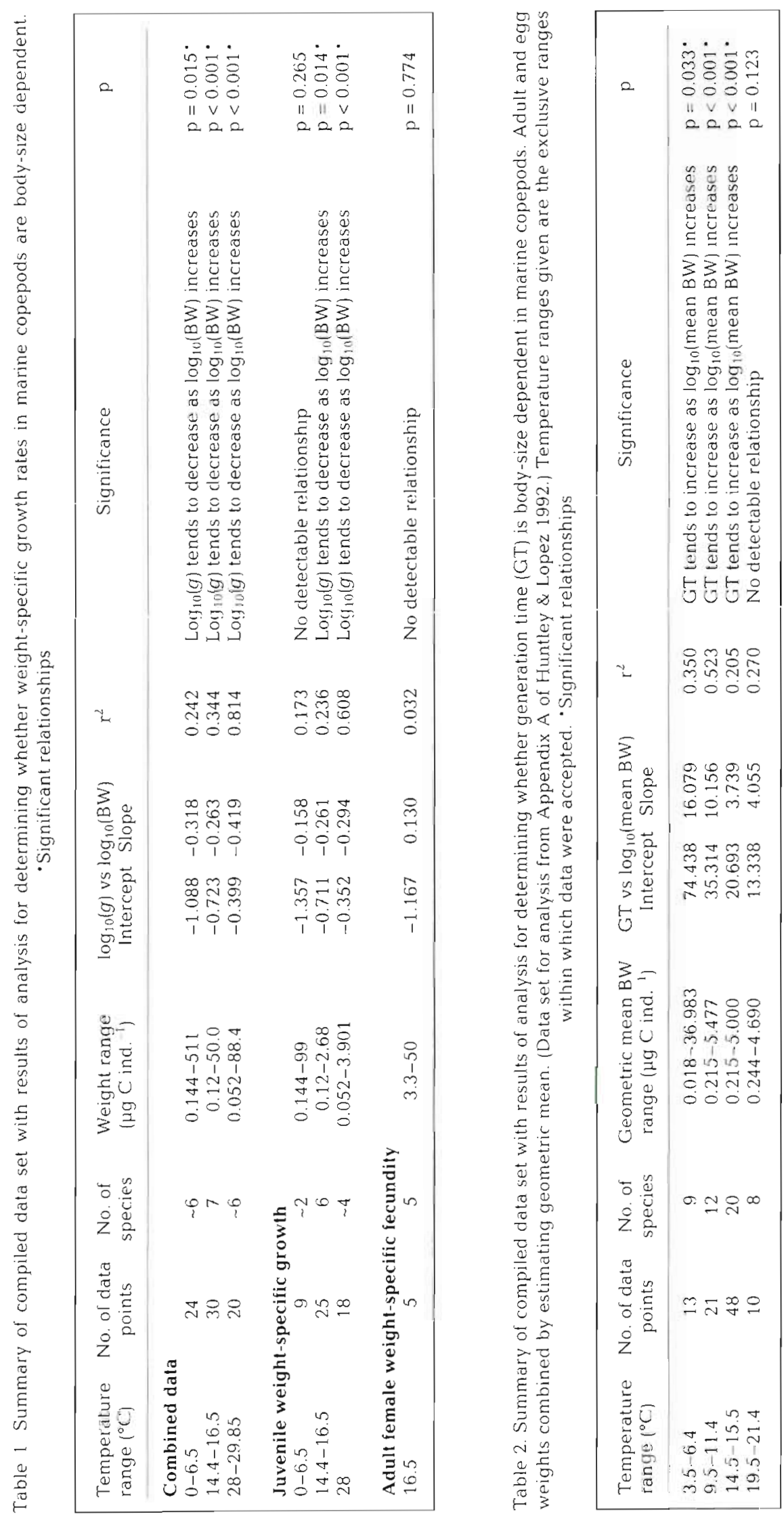
the entire data set. Several studies have reported decreasing weight-specific growth with increasing body size between marine copepod species (Roff \& Tremblay 1984, Peterson et al. 1991, see Hopcroft \& Roff 1995). Hopcroft \& Roff (1995) state that 'the growth rates obtained for Paracalanus are in good agreement with other growth rates obtained in Jamaica ... and an emerging picture relating growth rate to copepod size ... which suggest that $P$. crassirostris, by the virtue of it being the smallest calanoid copepod in this ecosystem, also has the highest growth rates'. Roff \& Tremblay (1984) describe how they 'regressed the data summarized by Greve (1978, Table 3) of body weight and daily $\mathrm{P} / \mathrm{B}^{\prime}$ and found that 'There is a highly significant relationship $\left(\mathrm{R}^{2}=87.9 \%\right.$, $p<0.001)$ '. Huntley \& Lopez (1992) found no detectable relationship between juvenile weight-specific growth rates and the weight of the adult form. However, their growth rate estimates were derived from generation time, and they pooled food-saturated laboratory rates and in situ rates. To generate the predicted growth rates they also assumed that growth was exponential, that is, weight independent over the life-history for each determination, and so could be described by a single number. Growth was also regressed against adult female weight, whereas actual weights of the growing individuals over short periods were used in this study.

Kiorboe \& Sabatini (1995) compiled food-saturated copepod growth data and found that while juvenile growth appears to be invariant with size (growth rates were once again regressed against adult female size), the weight-specific fecundity of females does show a significant decline with increasing body weight. It is notable that when the entire data set of Kiorboe \& Sabatini (1995) for juveniles and adults is combined $\left(\log _{10} g\right.$ vs $\log _{10}$ adult female body weight), the final relationship has a negative slope (slope $=-0.09$, intercept $=-0.607)$ and is significant $(p<0.05)$. It would appear that whilst juvenile food-saturated growth rates may be generally body-weight independent i.e. Kiørboe \& Sabatini 1995), the present study shows in situ juvenile growth declines with increasing body weight. This may reflect food being limiting in a bodysize dependent way under natural conditions, with larger individuals being more food limited. Adult in situ weight-specific fecundity was not significantly related to body weight in the present study; however, the data was very limited, with only 5 data points. Kiorboe \& Sabatini (1995) found declining maximum adult weight-specific fecundity with increasing body weight. The differences between the results of Kiorboe \& Sabatini (1995) and those found in this study may simply be a result of insufficient data within the present study.
Greater differences between measured growth and Huntley-Lopez predicted growth are apparent in Fig 1 at larger body weights, both for juvenile and adult rates. Individuals with body weights less than $\sim 0.1$ to $1 \mu \mathrm{g} \mathrm{C}$ often grow at rates similar to the Huntley-Lopez predictions (which may be an optimal rate), those larger than this appear to commonly grow at rates which are lower than the Huntley-Lopez predictions. This suggests a greater difference between optimal and in situ growth for larger species compared to smaller species.

Vital rates are generally described by allometric equations, either in the absolute form:

$$
V=a W^{b}
$$

or the weight-specific form:

$$
v=a W^{b-1}
$$

where $V$ is the absolute vital rate, and $v$ is the weightspecific vital rate, and $a$ and $b$ are constants. In the present study the slopes of $\log _{10}$ weight-specific growth versus $\log _{10}$ body weight for the entire data set varied between -0.419 and -0.263 . For each of the temperature bands chosen (see Fig. 1) $b=0.581\left(28\right.$ to $29.85^{\circ} \mathrm{C}$ group), $0.682\left(0\right.$ to $6.5^{\circ} \mathrm{C}$ group) and $0.737(14.4$ to $16.5^{\circ} \mathrm{C}$ groupl. Zooplankton allometric $b$ values have been found to vary from 0.670 to 0.959 for respiration, 0.486 to 0.902 for excretion, and 0.33 to 1.092 for clearance, ingestion and daily ration (see Ikeda 1977, Dagg et al. 1982, Ikeda \& Mitchell 1982, Vidal \& Whitledge 1982, Huntley \& Boyd 1984, Peters \& Downing 1984, Uye \& Yashiro 1988, Uye et al. 1990, Atkinson 1994, 1996). Most $b$ values for respiration, excretion and ingestion therefore centre around 0.6 to 0.8 , which is similar to the significant relationships in this study. Båmstedt \& Skjoldal (1980) and Banse \& Mosher (1980) also reported values of $b$ for population and individual growth in zooplankton of 0.63 and 0.683 .

Uye \& Yashiro (1988) found for zooplanktonic Crustacea collected from the Inland Sea of Japan that for regression slopes of $\log _{10}$ respiration rate versus $\log _{10}$ body weight, there were significant differences in the slope between the highest temperature regression (for summer) and those for autumn and spring, although autumn and spring gave relationships without significantly different slopes. In the present study there was no apparent trend in the slope of the regressions of growth rates of copepods (when considering juvenile and adult rates together) with temperature change when comparing between the small range temperature groups (Fig 1; Table 1). However, the slope does increase with temperature for the case of the multiple linear regression, although much less so than in the predictions of the Ikeda-Motoda model. Ikeda (1974) found that the slope of the regression for respiration of zooplankton decreased significantly with increased 
temperature, from $b=0.783$ (boreal species) to $b=$ 0.595 (tropical species), while the intercept increased significantly with increasing temperature. In Vidal \& Whitledge's (1982) re-evaluation of the crustacean data of Ikeda $(1970,1974)$, incorporating data of their own, they found that the slope was independent of temperature, but the intercept increased with increasing temperature. For the entire data set compiled in this study, intercept values do increase consistently with each increase in temperature when comparing the temperature groupings (see Table 1).

Both the Ikeda-Motoda and Huntley-Lopez models produced weight-specific growth rates which were significantly different from the data values compiled here. Comparing the Ikeda-Motoda and HuntleyLopez predictions to the actual measurements one finds that they give the best prediction on an equal number of accasions, when best prediction is defined as the model yiving the lowest (measured $g$ - predicted $g)^{2}$ value. As the entire data set shows weight dependence, one must therefore address the question as to why the weight-dependent model does not give the closest value on most occasions. For sub-tiopical and tropical species (i.e. at $>20.2^{\circ} \mathrm{C}$; see original data in Ikeda 1974), the Ikeda \& Motoda (1975) model includes respiration measurements of individuals with body weights of 8 to $40000 \mu \mathrm{g} \mathrm{C}$ ind. ${ }^{-1}$. However, an attempt was made here to predict the growth of individuals with body weights from 0.052 to $88.4 \mu \mathrm{g} \mathrm{C}$ ind. ${ }^{-1}$ Whereas at temperatures $<20^{\circ} \mathrm{C}$ there was little or no extrapolation in the prediction, at the highest temperatures this was necessary. Comparing extrapolated predictions of respiration rates from the Ikeda \& Motoda (1975) equations with measured rates of Uye \& Yashiro (1988) demonstrates that the former may be too high when considering rates under conditions of $>20^{\circ} \mathrm{C}$ and body weights below $0.4 \mu \mathrm{g} \mathrm{C}$ ind ${ }^{-1}$. If one only considers those growth predictions made at temperatures below $20^{\circ} \mathrm{C}$ then the Ikeda-Motoda model not only gives a closer prediction more often than the Huntley-Lopez model, but also the best overall prediction [assessed by summing the individual (measured $g$-predicted $g)^{2}$ values]. The apparent overestimation of growth rates by the Ikeda-Motoda model under low body weight-high temperature conditions is clearly demonstrated in Fig. 1c.

The present study shows a decrease in weight-specific growth of juveniles with increasing body weight. It is known that egg weight decreases as a proportion of adult female weight in broadcast spawners, and is constant with increasing size in sac spawners (Kiørboe \& Sabatini 1995). Given these 2 observations, it may be expected for there to be increasing generation times with increasing weight at a single temperature. There is preliminary confirmation of this in the re-analysis of the compiled data of Huntley \& Lopez (1992). Regressing generation time against geometric mean weights of copepods demonstrates that generation times may indeed be body-size dependent, with increasing generation time accompanying increases in body weight.

Growth rates derived from field generation times, as in the Huntley-Lopez model, may be biased by the fact that cohorts of copepods may grow asynchronously, and slower growing individuals may have greater rates of mortality (Lopez 1991). They may also be biased when peaks in abundance are used to follow growth, as these peaks are made up of optimally growing individuals (Carlotti \& Nival 1991). This has implications for the Huntley-Lopez model, leading to an overestimation of mean population growth rates (Kleppel et al, 1996). Whereas growth determined by shortterm incubations will include measurements of suboptimally growing individuals, which survive for the short incubation period but may not survive to adult, the use of generation time to estimate growth does not include such individuals. Short-term incubation procedures will therefore be less biased by the fact that sluwer yruwing individuais may have higner rates of mortality. Growth measured using typical short-term incubation techniques (e.g. Kimmerer \& McKinnon 1987, Peterson et al. 1991) may underestimate growth as a result of the removal of predators when they prey more heavily upon slower growing individuals. However, given typical removal rates over short-term incubations, the errors are likely to be minimal.

The experimental data used in this study to produce the equation relating growth to temperature and individual body weight may be criticized. Artifact and experimental errors are associated with most methods used to estimate growth (Huntley 1996). However, at present there seems little alternative to measuring growth over short time intervals under conditions as close to natural as possible. There would appear to be no a priori reasons to believe that these errors may act in such a consistent way as to bring about weight dependence when there is none. Copepods typically dominate net samples of mesozooplankton (Lalli \& Parsons 1993), and the empirical model may next be extended to allow estimation of growth of suites of zooplanktonic organisms in such samples. Taxonomic identification may be of less relevance when using this equation. Methods to measure and predict biomass also need to be developed, as these components of the production equation may be more variable than the growth component (Huntley \& Lopez 1992, Huntley 1996). Further analysis of the type undertaken here should be conducted as appropriate data becomes available. The topic of whether female in situ weightspecific fecundity is body-weight dependent needs particular attention. 
Appendix 1. Compilation of weight-specific growth $(g)$, body weight and temperature for marine copepods. Growth rates from short-term incubation procedures. Production type: adult female fecundity (A); juvenule somatic growth (J); not specified (ns). Sources: 1, Peterson et al. (1991) - adult data taken from average values of their Tables IV \& Vl, non-adult values from W. $T$ Peterson; 2. Kimmerer (1980) - taken from his Table 9; 3. Schnack et al. (1985); 4, Gerber \& Gerber (1979); 5, Chisholm \& Roff (1990b); 6, Newbury \& Bartholomew (1976); and 7, Burkill \& Kendall (1982). NB: For the Chisholm \& Roff (1990b) study, copepod body weights (geometric mean over period) were derived from the length-weight and mean lengths given in Tables 1 \& 3 of Chisholm \& Roff $(1990$ a). The data were from a tropical region in which mean prosome lengths in most cases showed no significant seasonal chânge

\begin{tabular}{|c|c|c|c|c|c|c|c|c|c|c|c|}
\hline Species & $\begin{array}{l}\text { Prod. } \\
\text { type }\end{array}$ & $\begin{array}{l}\text { Temp. } \\
\left({ }^{\circ} \mathrm{C}\right)\end{array}$ & $\begin{array}{c}\text { Body } \\
\text { welght } \\
\left(\mu g C \text { ind } .^{-1}\right)\end{array}$ & $\begin{array}{c}g \mathrm{~S} \\
\left(\mathrm{~d}^{-1}\right)\end{array}$ & Source & Species & $\begin{array}{l}\text { Prod. } \\
\text { type }\end{array}$ & $\begin{array}{l}\text { Temp. } \\
\left({ }^{\circ} \mathrm{C}\right)\end{array}$ & $\begin{array}{c}\text { Body } \\
\text { weight } \\
\left(\mu \mathrm{C}_{\mathrm{C}} \mathrm{ind}^{-1}\right)\end{array}$ & $\begin{array}{l}g \mathrm{~S} \\
\left(\mathrm{~d}^{-1}\right)\end{array}$ & Source \\
\hline \multicolumn{6}{|l|}{ Acartiidae } & \multicolumn{6}{|l|}{ Paracalanidae } \\
\hline Acartia longiremis & J & 16.5 & 0.48 & 0.22 & 1 & Paracalanus sp. & $\mathrm{J}$ & 28 & 0.052 & 1.073 & 6 \\
\hline A. longiremis & $\mathrm{J}$ & 16.5 & 0.8 & 0.11 & 1 & Paracalanus sp. & $\mathrm{J}$ & 28 & 0.108 & 1.541 & 6 \\
\hline A. longiremis & A & 16.5 & 4.4 & 0.07 & 1 & Paracalanus sp. & $\mathrm{J}$ & 28 & 0.276 & 0.552 & 6 \\
\hline \multirow{2}{*}{\multicolumn{6}{|c|}{ Acrocalanidae }} & Paracalanus sp. & J & 28 & 0.4 & 0.854 & 6 \\
\hline & & & & & & Paracalanus sp. & $\mathrm{J}$ & 28 & 0.728 & 0.464 & 6 \\
\hline $\begin{array}{l}\text { Acrocaldius inerinis } \\
\text { A. inermis }\end{array}$ & J & $\begin{array}{l}24.5 \\
24.5\end{array}$ & $\begin{array}{l}0.018 \\
0.024\end{array}$ & $\begin{array}{l}0.36 \\
0.78\end{array}$ & 2 & Paracalanus aculeatu & us $\mathrm{J}$ & 28 & 0.146 & 0.58 & 5 \\
\hline A. inermis & $\mathrm{J}$ & 24.5 & $\begin{array}{l}0.024 \\
0.032\end{array}$ & $\begin{array}{l}0.78 \\
1.18\end{array}$ & 2 & P. aculeatus & J & 28 & 0.355 & 0.65 & 5 \\
\hline A. inermis & J & 24.5 & 0.044 & $\begin{array}{l}1.18 \\
1.22\end{array}$ & $\begin{array}{l}2 \\
2\end{array}$ & P. aculeatus & $\mathrm{J}$ & 28 & 0.742 & 0.38 & 5 \\
\hline A. inermis & $\mathrm{J}$ & 24.5 & 0.0525 & $\begin{array}{l}1.22 \\
0.56\end{array}$ & $\begin{array}{l}2 \\
2\end{array}$ & P. aculeatus & J & 28 & 1.212 & 0.29 & 5 \\
\hline A. inermis & J & 24.5 & 0.07 & 0.28 & 2 & \multicolumn{6}{|l|}{ Pseudocalanidae } \\
\hline A. inermis & J & 24.5 & 0.0795 & 0.24 & 2 & Pseudocalanus sp. & $\mathrm{J}$ & 16.5 & 0.12 & 0.23 & 1 \\
\hline A. inermis & J & 24.5 & 0.0935 & 0.52 & 2 & Pseudocalanus sp. & $\mathrm{J}$ & 16.5 & 0.2 & 0.27 & 1 \\
\hline A. inermis & $\mathrm{J}$ & 24.5 & 0.163 & 0.82 & 2 & Pseudocalanus sp. & $\mathrm{J}$ & 16.5 & 0.32 & 0.23 & 1 \\
\hline A. inermis & $\mathrm{J}$ & 24.5 & 0.3095 & 0.86 & 2 & Pseudocalanus sp. & J & 16.5 & 0.48 & 0.35 & 1 \\
\hline A. inermis & J & 24.5 & 0.595 & 0.76 & 2 & Pseudocalanus sp. & $\mathrm{J}$ & 16.5 & 0.72 & 0.26 & 1 \\
\hline A. inermis & J & 24.5 & 0.825 & 0.31 & 2 & Pseudocalanus sp. & $\mathrm{J}$ & 16.5 & 1.24 & 0.20 & $\hat{1}$ \\
\hline A. inermis & A & 24.5 & 0.9 & 0.14 & 2 & Pseudocalanus sp. & $\mathrm{J}$ & 16.5 & 2.0 & 0.15 & 1 \\
\hline \multicolumn{6}{|l|}{ Calanidae } & \multicolumn{6}{|l|}{ Temoridae } \\
\hline Calanus finmarchicu & US A & 16.5 & 50 & 0.11 & 1 & Eurytemora affinis & J & 9.9 & 0.612 & 0.198 & 7 \\
\hline Calanus propinquus & $5 \mathrm{~J}+\mathrm{A}$ & 0 & 230 & 0.0274 & 43 & E. affinis & $\mathrm{J}$ & 9.9 & 1.04 & 0.107 & 7 \\
\hline C. propinquus & $J+A$ & 0 & 209 & 0.0555 & 53 & E. affinis & $\mathrm{J}$ & 9.9 & 1.528 & 0.073 & 7 \\
\hline C. propinquus & $\mathrm{J}+\mathrm{A}$ & 0 & 220 & 0.0136 & 363 & E. affinis & $\mathrm{J}$ & 9.9 & 0.612 & 0.198 & 7 \\
\hline Calanoides acutus & $\mathrm{J}+\mathrm{A}$ & 0 & 133 & 0.0038 & $\begin{array}{ll}88 & 3 \\
8 & 2\end{array}$ & E. affinis & J & 9.9 & 1.04 & 0.108 & 7 \\
\hline C. acutus & $\mathrm{J}+\mathrm{A}$ & 0 & 141 & 0.0418 & 83 & E. affinis & $\mathrm{J}$ & 9.9 & 1.528 & 0.073 & 7 \\
\hline C. acutus & $\mathrm{J}+\mathrm{A}$ & 0 & 135 & 0.0037 & 373 & E. affinis & $\mathrm{J}$ & 14.4 & 0.9 & 0.18 & 7 \\
\hline Undinula vulgaris & ns & 29.85 & 88.4 & 0.048 & 4 & E. affinis & $\mathrm{J}$ & 14.4 & 1.38 & 0.079 & 7 \\
\hline \multicolumn{6}{|l|}{ Centropagidae } & E. affinis & $\mathrm{J}$ & 14.4 & 0.9 & 0.18 & 7 \\
\hline Centropages typicus & $s \quad \mathrm{~J}$ & 16.5 & 0.52 & 0.28 & 1 & E. affinis & $\mathrm{J}$ & 14.4 & 1.388 & 0.082 & 7 \\
\hline C. typicus & J & 16.5 & 1.04 & 0.34 & 1 & E affinis & $\mathrm{J}$ & 6.5 & 0.144 & 0.1 & 7 \\
\hline C. typicus & $\mathrm{J}$ & 16.5 & 2 & 0.28 & 1 & E. affinis & J & 6.5 & 0.204 & 0.064 & 7 \\
\hline C. typicus & A & 16.5 & 12.3 & 0.25 & 1 & E. affinis & $\mathrm{J}$ & 6.5 & 0.312 & 0.044 & 7 \\
\hline \multirow{2}{*}{\multicolumn{2}{|c|}{$\begin{array}{c}\text { Centropages } \\
\text { verificatus }\end{array}$}} & 28 & 0.442 & 0.62 & 5 & E. affinis & $\mathrm{J}$ & 6.5 & 0.416 & 0.144 & 7 \\
\hline & & & & & & E. affinis & $\mathrm{j}$ & 6.5 & 0.9 & 0.024 & 7 \\
\hline C. verificatus & J & 28 & 1.012 & 0.50 & 5 & E. affinus & $\mathrm{j}$ & 6.5 & 1.26 & 0.012 & 7 \\
\hline C. verificatus & $\mathrm{J}$ & 28 & 2.150 & 0.44 & 5 & Temora longicornis & $\mathrm{J}$ & 16.5 & 0.12 & 0.39 & 1 \\
\hline C. verificatus & $\mathrm{J}$ & 28 & 3.901 & 0.38 & 5 & $T$ longicornis & $\mathrm{J}$ & 16.5 & 0.2 & 0.35 & 1 \\
\hline \multirow{2}{*}{\multicolumn{6}{|c|}{ Eucalanidae }} & $T$ longicornis & $\mathrm{J}$ & 16.5 & 0.28 & 0.20 & 1 \\
\hline & & & & & & T longicornis & $\mathrm{J}$ & 16.5 & 0.56 & 0.37 & 1 \\
\hline Rhincalanus gigas & $\mathrm{J}+\mathrm{A}$ & 0 & 503 & 0.001 & 3 & $T$ longicornis & A & 16.5 & 9.4 & 0.03 & 1 \\
\hline R. gigas & $\mathrm{J}+\mathrm{A}$ & 0 & 511 & 0.0084 & 343 & Temora turbinata & J & 28 & 0.352 & 0.40 & 5 \\
\hline R. gigas & $\mathrm{J}+\mathrm{A}$ & 0 & 492 & 0.0006 & 663 & T. turbinata & J & 28 & 0.637 & 0.44 & 5 \\
\hline \multicolumn{6}{|l|}{ Metridiidae } & T. turbinata & $J$ & 28 & 1.181 & 0.45 & 5 \\
\hline Metrida gerlachei & $\mathrm{J}+\mathrm{A}$ & 0 & 162 & 0.0568 & 83 & T. turbinata & $\mathrm{J}$ & 28 & 1.987 & 0.27 & 5 \\
\hline M. gerlachej & $\mathrm{J}+\mathrm{A}$ & 0 & 161 & 0.0901 & 13 & $T$ turbinata & $\mathrm{J}$ & 28 & 2.941 & 0.40 & 5 \\
\hline M. gerlachel & $\mathrm{J}+\mathrm{A}$ & 0 & 159 & 0.0195 & 53 & \multirow{2}{*}{\multicolumn{6}{|c|}{ Assorted species }} \\
\hline \multicolumn{6}{|l|}{ Paracalanidae } & & ds ns & 29.85 & 9.3 & 0.086 & 4 \\
\hline Paracalanus parvus & $\mathrm{J}$ & 16.5 & 0.24 & 0.25 & 1 & Small copepods & $\mathrm{J}+\mathrm{A}$ & 0 & 7 & 0.5000 & 03 \\
\hline P. parvus & $\mathrm{J}$ & 16.5 & 0.44 & 0.35 & 1 & Small copepods & $\mathrm{J}+\mathrm{A}$ & 0 & 6 & 1.0833 & 33 \\
\hline P. parvus & J & 16.5 & 0.8 & 0.23 & 1 & Small copepods & $J+A$ & 0 & 8 & 0.1875 & 53 \\
\hline P. parvus & J & 16.5 & 1.52 & 0.38 & 1 & Copepodids & J & 0 & 82 & 0.0341 & 13 \\
\hline P. parvus & $\mathrm{J}$ & 16.5 & 2.68 & 0.1 & 1 & Copepodids & J & 0 & 99 & 0.0778 & 83 \\
\hline P. parvus & A & 16.5 & 3.3 & 0.11 & 1 & Copepodids & $\mathrm{J}$ & 0 & 69 & 0.0058 & 83 \\
\hline
\end{tabular}


Acknowledgements. A.G.H. was funded by a Natural Environment Research Council Studentship (GT/4/92/261/A). The authors thank Angus Atkınson, Peter Ward and Richard Lampitt for helpful comments on drafts of the manuscript, and to the reviewers, whose comments helped greatly in clarifying the paper.

\section{LITERATURE CITED}

Aksnes DL, Magnesen T (1988) A population dynamics approach to the estimation of production of four copepods in Lindáspollene, western Norway. Mar Ecol Prog Ser 45:57-68

Alldredge: AL (1984) The quantitative significance of gelatinous zooplankton as pelagic consumers. In: Fasham MJR (ed) Flows of energy and materials in marine ecosystems: theory and practice. Plenum Press, London, p 407-433

Atkinson A (1994) Diets and feeding selectivity among the epipelagic copepod community near South Georgia in summer. Polar Biol 14:551-560

Atkinson A (1996) Subantarctic copepods in an oceanic, low chlorophyll environment: ciliate predation, food selectivity and inupdit un prey popuiations. Mar Ecol Prog Ser 130: $85-96$

Bămstedt U (1986) Chemical composition and energy content. In: Corner EDS, O'Hara SCM (eds) The biological chemistry of marine copepods. Clarendon Press, Oxford, p 1-58

Buinstedt U, Skjuidal HR (1980) RNA concentration of zooplankton: relationship with size and growth. Limnol Oceanogr 25:304-316

Banse K, Mosher S (1980) Adult body mass and annual production/biomass relationships of field populations. Ecol Monogr 50:355-379

Burkill PH, Kendall TF (1982) Production of the copepod Eurytemora affinis in the Bristol Channel. Mar Ecol Prog Ser $7: 21-31$

Carlottı F, Nival S (1991) Individual variability of development in laboratory-reared Temora stylifera copepodites: consequences for the population dynamics and interpretation in the scope of growth and development rules. J Plankton Res 13:801-813

Chisholm LA, Roff JC (1990a) Size-weight relationships and biomass of tropical neritic copepods off Kingston, Jamaica. Mar Biol 106:71-77

Chisholm LA, Roff JC (1990b) Abundances, growth rates, and production of tropical neritic copepods off Kingston, Jamaica. Mar Biol 106:79-89

Dagg MJ, Littlepage JL (1972) Relationships between growth rate and RNA, DNA, protein and dry weight in Artemia salina and Euchaeta elongata. Mar Biol 17:162-170

Dagg MJ, Vidal J, Whitledge TE, Iverson RL, Goenng JJ (1982) The feeding, respuration, and excretion of zooplankton in the Bering Sea during a spring bloom. Deep Sea Res 29:45-63

Gerber RP, Gerber MB (1979) Ingestion of natural particulate organic matter and subsequent assimilation, respiration and growth by tropical lagoon zooplankton. Mar Biol 52:33-43

Greve VN (1978) Production in anımal populations. In: Kinne $O$ (ed) Marine ecology, Vol 4. John Wiley and Sons, Chichester, p 89-114

Hay S (1995) Egg production and secondary production of common North Sea copepods: field estimates with regional and seasonal comparisons. ICES J Mar Sci 52 : $315-327$

Hopcroft RR, Roff JC (1995) Zooplankton growth rates: extraordinary production by the Iarvacean Oikopleura dıoica in tropical waters. J Plankton Res 17:205-220
Huntley ME (1996) Temperature and copepod production in the sea: a reply. Am Nat 148:407-420

Huntley M, Boyd C (1984) Food-limited growth of marne zooplankton. Am Nat 124:455-478

Huntley ME, Lopez MDG (1992) Temperature-dependent production of marine copepods: a global synthesis. Am Nat 140:201-242

Hutchings L, Verheye HM, Painting SJ, Huggett JA, MitchellInnes BA, Plaganyi E (1995) Copepod production in the southern Benguela upwelling system. ICES J Mar Sci 52 $439-4.55$

Ikeda I (1970) Relationship between respiration rate and body size in marine plankton animals as a function of the temperature of habitat. Bull Fac Fish Hokkaido Univ 21. $91-112$

lkeda T (1974) Nutritional ecology of marine zooplankton. Mem Fac Fish Hokkaido Univ 22:1-97

Ikeda T (1977) Feeding rates of planktonic copepods from a tropical sea. J Exp Mar Biol Ecol 29:263-277

Ikeda T, Mitchell AW (1982) Oxygen uptake, ammonia excretion and phosphate excretion by krill and other Antarctic zooplankton in relation to their body size and chemical composition. Mar Biol 71:283-298

Ikeda T. Motoda S (1975) An approach to the estimation of zooplankton production in the Kuroshio and adjacent regions. In: Morton B (ed) Special Symposium on Marine Sciences. Pac Sci Assoc, Hong Kong, p 24-28

Ikeda J, Motoda S (1978) Estimated zooplankton production and their ammonia excretion in the Kuroshio and adjacent seas. Fish Bull 76:357-367

Joh $\mathrm{H}$, Uno $\mathrm{S}$ (1983) Zooplankton standing stock and their estimated production in Osaka Bay. Bull Plankton Soc Jpn 30:41-51 (in Japanese with English abstract)

Kımmerer WJ (1980) Plankton patchiness and ecosystem stability. PhD dissertation, University of Hawaii, Honolulu

Kimmerer WJ, McKinnon AD (1987) Growth, mortality, and secondary production of the copepod Acartia tranten in Westernport Bay, Australia. Limnol Oceanogr 32:14-28

Kiørboe T, Sabatini M (1995) Scaling of fecundity, growth and development in marine planktonic copepods. Mar Ecol Prog Ser 120:285-298

Kleppel GS, Davis CS, Carter K (1996) Temperature and copepod growth in the sea: a comment on the temperature-dependent model of Huntley and Lopez. Am Nat 148 $397-406$

Koga H (1986) The occurrence and production of zooplankton in Sudo-Nada, western Seto Inland Sea. Bull. Nansei Reg Fish Res Lab 20:91-113 (in Japanese with English abstract)

Lalli CM, Parsons TR (1993) Biological oceanography: an introduction. Pergamon Press, Oxford

Lopez MDG (1991) Molting and mortality dependent on age and stage in naupliar Calanus pacificus: implicatıons for development time of field cohorts. Mar Ecol Prog Ser 75:79-89

Mckinnon AD (1996) Growth and development in the subtropical copepod Acrocalanus gibber. Limnol Oceanogr $41: 1438-144$ ?

Newbury TK, Bartholomew EF (1976) Secondary production of microcopepods in the southern eutrophic basin of Kaneohe Bay, Oahu, Hawaiian Islands. Pac Scl 30: $373-384$

Omorı M. Ikeda T (1984) Methods in marine zooplankton ecology. John Wiley and Sons, New York

Parsons TR, Takahashi M. Hargrave B (1984) Biological oceanographic processes. Pergamon Press, New York

Peters RH, Downing JA (1984) Empirical analysis of zooplankton filterıng and feeding rates. Limnol Oceanogr 29 : $763-784$ 
Peterson WT, Hutchungs L (1995) Distribution, abundance and production of the copepod Calanus agulhensis on the Agulhas Bank in relation to spatial variations in hydrography and chlorophyll concentration. J Plankton Res 17:2275-2294

Peterson WT, Tiseluus P, Kiorboe T (1991) Copepod egg production, moulting and growth rates, and secondary production, in the Skagerrak in August 1988. J Plankton Res 13:131-154

Roff JC, Tremblay MJ (1984) Reply with additional notes on P/B ratios. Can J Fish Aquat Sci 41:830-833

Ross M (1982) Energetics of Euphausia pacifica. II. Complete carbon and nitrogen budgets at $8^{\circ}$ and $12^{\circ} \mathrm{C}$ throughout the life span. Mar Biol 68:15-23

Schnack SB, Smetacek V, Bodungen BV, Stegmann P (1985) Utilization of phytoplankton by copepods in Antarctic waters during spring. In: Gray JS, Christiansen ME (eds) Marine biology of polar regions and effects of stress on marine organisms. John Wiley and Sons Ltd, Chichester, p $65-81$

Uye Sl, Imaizumı K, Matsuda O (1990) Size composition and estimated phosphorus regeneration rates of the copepod community along an estuarine-offshore transect in the Inland Sea of Japan. Estuar Coast Shelf Sci 31:851-863

This article was submitted to the editor
Uye Sl, Kuwata H, Endo T (1987) Standing stock and production rates of phytoplankton and planktonic copepods in the inland sea of Japan. J Oceanogr Soc Jpn 42 : $421-434$

Uye Sl, Yashıro M (1988) Respiration rates of planktonıc crustaceans from the Inland Sea of Japan with special reference to the effects of body weight and temperature. J Oceanogr Soc Jpn 44:47-51

Vidal J (1980) Physioecology of zooplankton. I. Eftects of phytoplankton concentration, temperature, and body size on the growth rate of Calanus pacificus and Pseidocalanus sp. Mar Biol 56:111-134

Vidal J, Whitledge TE (1982) Rates of metabolism of planktonic crustaceans as related to body weight and temperature of habitat. J Plankton Res 4:77-84

Zaika VE (1968) Age-structure dependence of the specific production' in zooplankton populations. Mar Biol 1. 311-315

Zaika VE, Malovitskaya LM (1968) Characteristıcs of variability of productivity per unit biomass for some zooplankton populations. (From: Structure and dynamics of aquatic communities and populations). Fish Res Bd Can, Translation Series No. 975

Manuscript recelved: November 21, 1996 Revised version accepted: Aprll 16, 1997 